\title{
ISOLATION, SCREENING AND IDENTIFICATION OF LEAD AND CADMIUM RESISTANT SULFUR OXIDIZING BACTERIA
}

\author{
Sana Ashraf ${ }^{1, *}$, Zahir Ahmad Zahir ${ }^{1}$, Hafiz Naeem Asghar ${ }^{1}$ and Muhammad Asghar ${ }^{2}$ \\ ${ }^{1}$ Institute of Soil \& Environmental Sciences, University of Agriculture, Faisalabad, Pakistan; \\ ${ }^{2}$ Department of Biochemistry, University of Agriculture, Faisalabad, Pakistan \\ "Corresponding author's e-mail: sanaashrafenv@gmail.com
}

\begin{abstract}
Sulfur oxidizing bacteria (SOB) oxidize elemental sulfur $\left(\mathrm{S}^{\circ}\right)$ or reduce sulfur compounds to generate sulfuric acid which reduces the $\mathrm{pH}$ of media. In this study, lead and cadmium tolerant SOB were isolated by using thiosulphate medium from samples collected from different ecologies and screened on account of $\mathrm{pH}$ reduction, sulfate ions production, phosphorus solubilization index and phosphorus bioleaching tests. Results indicated that sulfate ions production ( $800 \mathrm{mg} / \mathrm{L}$ by Bacillus $\mathrm{sp}$. strain SS-16) and phosphorus solubilization ( $713 \mathrm{mg} / \mathrm{L}$ by Bacillus sp. strain SS-16) from rock phosphate were significantly increased as compared to control due to $\mathrm{pH}$ reduction (net decrease of 4.52 points). The tolerance of isolated SOB by minimum inhibitory concentration (MIC) and minimum bacterial concentration (MBC) was evaluated at different concentrations of lead and cadmium and Bacillus sp. strain SS-16 showed its ability to tolerate lead and cadmium up to 1000 and $180 \mathrm{mg} / \mathrm{L}$, respectively. Organic acids production ability of three efficient isolated SOB (SS-4, SS-8 and Bacillus sp. SS-16) was evaluated under normal and stressed (lead and cadmium polluted) conditions. Results indicated that short chain organic acids amount increased under $\mathrm{Pb}$ and $\mathrm{Cd}$ stressed conditions as compared to normal medium. The isolated $\mathrm{SOB}$ were further studied for their morphological and biochemical properties. The most efficient bacterium belonged to sewage sludge ecology and was identified as Bacillus sp. SS-16.
\end{abstract}

Keywords: Sulfur oxidizing bacteria, phosphorous solubilization, MIC, MBC, heavy metal resistant bacteria, organic acid profiling

\section{INTRODUCTION}

Heavy metal pollution of soil has become global environmental problem due to intensively increasing industrialization and agricultural activities (Mcgrath et al., 1995). In Pakistan, there is an unchecked disposal of raw sewage from domestic and industrial areas on cropped soils. Concentrations of heavy metals $(\mathrm{Pb}, \mathrm{Cd}$ and $\mathrm{Cr})$ in vegetable fields irrigated with untreated sewage are advancing towards phytotoxic levels (Hussain, 2000; Qadir et al., 2000). Accumulation of heavy metals in crop plants through soil-root interface is a critical hazard (Sharma and Agrawal, 2006; Yoon et al., 2006; Maimon et al., 2009). Thus, under this scenario, there is a need to reclaim soil contaminated with heavy metals.

Phytoremediation, an emerging green technology is receiving much more attention for rehabilitation of soils polluted with heavy metals because it is non-intrusive and inexpensive means of remediating contaminated soils (Alkorta and Garbisu, 2001; Prasad and Freitas, 2003; Wei et al., 2004; Ali et al., 2013). Phytoremediation can take place in many ways, but phytoextraction is an in-situ promising environment friendly technique for the reclamation of polluted soil (Nascimento and Xing, 2006). But, the success of phytoextraction is hindered by less solubility of heavy metals in soil solution and low bioavailability to plants (Turgut et al., 2004). The use of elemental sulfur in soil has been suggested to decrease $\mathrm{pH}$ and increase solubility and bioavailability of heavy metals in soil (Kayser et al., 2000).

In Pakistan, the soils are mostly alkaline $(\mathrm{pH}>7)$ and calcareous $\left(\mathrm{CaCO}_{3}>3 \%\right)$ in nature (Sharif et al., 2000; Jafar et al., 2012) with $15 \%$ soils are poor in sulfur $(<10 \mathrm{mg} / \mathrm{kg}$ $\left.\mathrm{SO}_{4}^{-2}\right)$, and $30 \%\left(11-30 \mathrm{mg} / \mathrm{kg} \mathrm{SO}_{4}{ }^{-2}\right), 33 \%(31-99 \mathrm{mg} / \mathrm{kg}$ $\left.\mathrm{SO}_{4}^{-2}\right)$ and $22 \%\left(\mathrm{mg} / \mathrm{kg} \mathrm{SO}_{4}^{-2}\right)$ soils fall in acceptable, adequate and high range, respectively (NFDC, 1992; Sutaria, 2016). Sulfur is the most important plant nutrient after nitrogen, phosphorus and potassium (Jamal et al., 2010) and is a natural acidifying element. But due to greater fixation, low availability of plant nutrients is an immense issue. Plant roots take sulfur mainly in the form of sulfate $\left(\mathrm{SO}_{4}{ }^{-2}\right)$. Sulfur oxidizing bacteria ( $\mathrm{SOB}$ ) oxidize elemental sulfur into sulfate in alkaline calcareous soils and produce sulfuric acid which decreases the soil $\mathrm{pH}$ and increases the solubility and plant availability of nutrients (Hitsuda et al., 2005; Abdou, 2006; El-Tarabily et al., 2006) as well as heavy metals and thus improve the condition of alkali and heavy metal polluted soils.

Although, majority of the reported SOB are associated with genera Thiobacillus, Thiothrix, Thiomicrospira, Achromatium and Desulfuromonas, but heterotrophic bacteria 
also oxidize reduced sulfur compounds (Das et al., 1996). Most agricultural soils are deficient in Thiobacilli (Lawrence and Germida, 1991). Soils inoculated with sulfur oxidizing bacteria speed up the natural biological sulfur oxidation leading towards increased plant yield (Amal et al., 2014). Keeping this in view, the present study was conducted for isolation and screening of lead and cadmium resistant SOB.

\section{MATERIALS AND METHODS}

Sample collection and growth medium for isolation of $\mathrm{SOB}$ : Samples were collected from different ecologies like sewage sludge (SS), sulfur contaminated soil (SCS), sewage water (SW), industrial waste sludge (IWS), tannery effluent (TE), cow dung (CD) and normal soil (NS) and isolation of SOB was performed by using dilution plate technique on thiosulfate medium $\left(\mathrm{Na}_{2} \mathrm{~S}_{2} \mathrm{O}_{3}, 5.0 \mathrm{~g} ; \mathrm{K}_{2} \mathrm{HPO}_{4}, 0.1 \mathrm{~g}\right.$; $\mathrm{NaHCO}_{3}, 0.2 \mathrm{~g} ; \mathrm{NH}_{4} \mathrm{Cl}, 0.1 \mathrm{~g}$ dissolved in $1.0 \mathrm{~L}$ distilled water ) using bromo cresol purple as an indicator (Beijerinck, 1904). The $\mathrm{pH}$ of the medium was adjusted to 8.0 before sterilization. One gram or one milliliter of collected samples was added to $20 \mathrm{~mL}$ of the sterilized medium poured in test tubes. Then the tubes were incubated at $30^{\circ} \mathrm{C}$ for 14 days. Change in color from purple to yellow denoted the growth of SOB in the test tubes. Sewage sludge sample produced bright yellow color that indicated the presence of efficient SOB. Then $100 \mu \mathrm{L}$ of bacterial culture was poured on thiosulfate agar plates containing bromo cresol purple. After 3 days, growth was appeared and 23 individual colonies were picked and streaked on thiosulfate agar plates containing bromo cresol purple.

Screening of Efficient Isolates:

Color change: Among 23 colonies, 11 isolates were selected as effective SOB on the basis of color change on thiosulfate agar plates from purple to yellow and further analyzed for different parameters.

The $\mathrm{pH}$ reduction test: One milliliter fresh culture of selected isolates prepared in thiosulphate medium ( $\mathrm{pH}$ 8.0) was inoculated in flasks containing $20 \mathrm{~mL}$ thiosulphate medium with bromo cresol purple ( $\mathrm{pH} \mathrm{8.0)}$ and incubated at $30^{\circ} \mathrm{C}$ for 16 days. Screening of isolates was performed on the account of their capability to reduce the $\mathrm{pH}$ of medium. The $\mathrm{pH}$ of the samples was determined through $\mathrm{pH}$ meter (Kent Eil 7015, England). The experiment was conducted with three replications.

Sulfate ions production test: Sulfate ions produced during the growth of SOB in thiosulfate medium were determined by adding 1:1 barium chloride solution $(10 \% \mathrm{w} / \mathrm{v})$ in bacterial culture supernatant (Cha et al., 1999). White turbidity was appeared due to formation of barium sulfate. That turbidity was measured at $450 \mathrm{~nm}$ by spectrophotometer (ANA-720W, Tokyo Photo-electric Company Limited, Japan). The values obtained were compared with standard sulfate curve that was constructed by dissolving $\mathrm{K}_{2} \mathrm{SO}_{4}$ in distilled water (Kolmert et al., 2000). The experiment was performed with three replications.

Phosphorus solubilization index (PSI): For the determination of PSI, fresh culture of selected isolates $(0.1$ $\mathrm{mL}$ ) was placed on thiosulphate tricalcium phosphate (TCP) agar $(0.5 \%)$ plates and incubated for 8 days at $30^{\circ} \mathrm{C}$. The experiment was performed with three replications. Phosphorous solubilization zones were formed on agar plates and PSI was quantified by using the following formula (EdiPremono et al., 1996).

$$
\text { PSI }=\frac{\text { Colony diameter }+ \text { Holozone diameter }}{\text { Colony diameter }}
$$

Quantitative phosphorus solubilization: Phosphorous solubilzation efficiency of selected SOB was checked by rock phosphate bioleaching test. The experiment was performed with three replications. Each conical flask contained $100 \mathrm{~mL}$ thiosulphate medium ( $\mathrm{pH}$ 8.0) along with $0.5 \%$ rock phosphate. After autoclaving the flasks were inoculated with $1.0 \mathrm{~mL}$ broth culture of each selected isolate in 3 flasks, and 3 flasks were kept as un-inoculated control. The flasks were incubated $\left(100 \mathrm{rev} \mathrm{min}^{-1}\right)$ at $30^{\circ} \mathrm{C}$ for $16 \mathrm{~d}$. After 8 and 16 days of incubation, aliquot samples $(5 \mathrm{~mL})$ were drawn and centrifuged. The supernatants were analyzed for $\mathrm{P}$ solubilization. The amount of soluble $\mathrm{P}$ was calculated through molybdenum blue method (Watanabe and Olsen, 1965).

Minimum inhibitory concentration (MIC) and minimum bacterial concentration (MBC): MIC of selected SOB isolates for $\mathrm{Pb}$ and $\mathrm{Cd}$ was determined. The colonies were picked from formerly grown bacteria and streaked on the freshly LB agar medium supplemented with different concentrations of $\mathrm{Pb}$. The same procedure was repeated with isolated SOB under various concentrations of $\mathrm{Cd}$. The concentration of metals at which the number of colonies reduced as compared to control plate, was considered as MIC. After determination of MIC, MBC was determined. The concentration of metals at which no colony grew or the number of colonies was reduced by $99.9 \%$ as compared with the control plates, was considered as MBC (Zeng et al., 2009; Kafilzadeh et al., 2010; Shamim and Rehman, 2012). Lead nitrate $\left[\mathrm{Pb}\left(\mathrm{NO}_{3}\right)_{2}\right]$ and cadmium nitrate $\left[\mathrm{Cd}\left(\mathrm{NO}_{3}\right)_{2}\right]$ salts were used as a source of $\mathrm{Pb}$ and $\mathrm{Cd}$, respectively. The experiment was performed with three replications.

Analysis of organic acids produced by SOB: Organic acids production ability of three efficient isolated SOB, selected on the basis of above conducted tests, was determined under normal, lead (600 mg Pb L $\mathrm{mb}^{-1}$ ) and cadmium (80 mg Cd L-1) stressed medium following the method of Li et al. (2009). Levels of $\mathrm{Pb}$ and $\mathrm{Cd}$ applied to medium were selected through MIC and MBC. The experiment was conducted with three replications. Organic acids were determined by HPLC (Shimadzu, Japan) with LC-10 AT, UV-visible and SPD-10 $\mathrm{AV}$, after running the samples along with standards for organic compounds. 
Morphological and biochemical characterization of SOB: Colony and cell morphology of selected isolates was studied by the method of Bergey and Boone (2009). Gram staining was done by the method of Vincent (1970). Presence of catalase and oxidase in the selected SOB was identified following the methods described by MacFaddin (1980) and Steel (1961), respectively. Siderophores production was measured following the method of Schwn and Neilands (1987). Selected isolates were analyzed for their ability to utilize $S^{\circ}$. Isolates were inoculated in sterilized Starkey medium amended with $10 \mathrm{~g} \mathrm{~S}^{\circ}$ (Starkey, 1935) and incubated at room temperature for 15 days. Growth and elemental sulfur utilization were assessed by $\mathrm{pH}$ reduction of medium. Temperature tolerance test for selected isolates was performed. Isolates were inoculated in sterilized thiosulfate medium and incubated at different temperatures $(20,28,38$ and $45^{\circ} \mathrm{C}$ ) for 15 days and growth was observed (Priyanka $e t$ al., 2014).

Molecular identification of selected heavy metal tolerant SOB: The selected SOB isolate was identified by amplifying, sequencing and analyzing its $16 \mathrm{~S}$ rRNA gene sequence. For this purpose, crude DNA of the selected isolate Bacillus sp. SS-16 was separated from the cell culture using proteinase $\mathrm{K}$ treatment (Cheneby et al., 2004). The universal primers were used for PCR amplification (forward primer: 50'-AGA GTT TGA TCH TGG CTC AG-30' and reverse primer: 50'-TAC GGH TAC CTT GTT ACG ACT T-30'). The PCR reaction was performed by using $2.5 \mu \mathrm{L}$ crude DNA as a template (Hussain et al., 2011). The size of the amplified 16S rRNA was checked by segregating on $1 \%$ agarose gel along with GeneRuler 1kb DNA (Fermentas). The 16S rRNA PCR product was refined using a PCR Purification Kit (Favorgen, Taiwan) and sequenced by Macrogen (Seoul, Korea). 16S rRNA of Bacillus sp. SS-16 was matched with the known nucleotide sequences using BlastN (http://www.ncbi.nlm.nih.gov/BLAST). The phylogenetic tree was developed through multiple alignments using Mega 6 Software.

The data were analyzed using analysis of variance technique by Statistix 8.1 statistical package (Statistix, USA). Mean values were compared using Tukey's (HSD) test at $p<0.05$ (Steel et al., 1997). Means and standard errors were calculated with MS Excel, 2016.

\section{RESULTS}

All the collected samples from different ecologies i.e. sewage sludge (SS), sulfur contaminated soil (SCS), sewage water (SW), industrial waste sludge (IWS), tannery effluent (TE), cow dung (CD) and normal soil (NS), were tested for the presence of sulfur oxidizing bacteria. It is revealed from the data that different ecologies contain different number of SOB. However, highest population was observed in sewage sludge (Fig. 1). For further isolation sewage sludge was used and eleven strains were selected as SOB on the basis of color change.

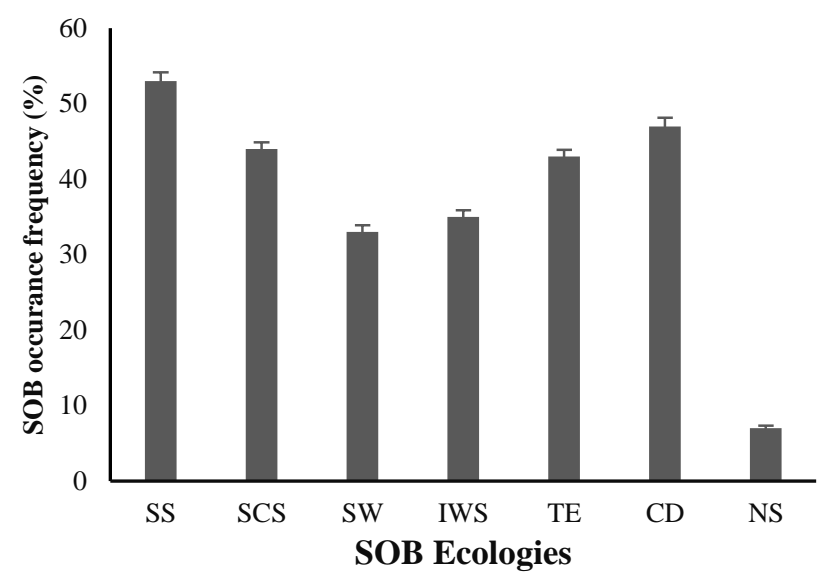

Figure 1. Frequency of sulfur oxidizing bacteria in the sampling ecologies indicating highest number of SOB in sewage sludge (average of three replicates). SS (sewage sludge), SCS (sulfur contaminated soil), SW (sewage water), IWS (industrial waste sludge), TE (tannery effluent), CD (cow dung), NS (normal soil).

Figure 2 shows the effect of 11 selected SOB isolates on $\mathrm{pH}$ reduction of thiosulfate medium during 16 days of incubation. Data reveals that maximum reduction (net decrease of 4.52 points) in $\mathrm{pH}$ was recorded in case of Bacillus sp. SS-16 (Fig. 3) after 16 days of inoculation followed by SS-8 with $3.72 \mathrm{pH}$ (net decrease of 4.28 points). While the minimum decrease was observed in isolate SS-21 giving a $\mathrm{pH}$ value of 5.37 (net decrease of 2.63 points). Four SOB isolates SS-4 (3.86), SS-7 (4.10), SS-2 (4.18) and SS-13 (4.25) showed pH value between 3.86 and 4.25 (net decrease in $\mathrm{pH}$ of 3.75 to 4.14 points). After eight days of inoculation, Bacillus sp. isolate SS-16 gave maximum significant reduction in $\mathrm{pH}$ (3.78) of thiosulfate medium with net decrease in $\mathrm{pH}$ of 4.22 points followed by the SS- 8 with $4.12 \mathrm{pH}$ (net decrease in $\mathrm{pH}$ of 3.88). pH of 6 SOB SS-1 (5.10), SS-2 (4.55), SS-4 (4.25), SS-7 (4.49), SS-11 (4.90), SS-13 (4.67) and SS-17 (4.78) ranged from 4.25 to 5.10 with net decrease in $\mathrm{pH}$ ranging from 3.10 to 3.75 points. Isolates SS-3 (7.21) and SS-21 (7.49) gave minimum net reduction in $\mathrm{pH}$ that ranged from 0.51 to 0.79 points.

The results revealed that nine isolates out of eleven produced free sulfate contents at $8^{\text {th }}$ day of incubation while at $16^{\text {th }}$ day of incubation, all SOB isolates produced the free sulfate contents (Fig. 4). Bacillus sp. isolate SS-16 produced highest amount $(801 \mathrm{mg} / \mathrm{L})$ of sulfate ions at $16^{\text {th }}$ day of incubation while same isolate produced the sulfate ions of $480 \mathrm{mg} / \mathrm{L}$ at $8^{\text {th }}$ day of incubation. Isolates SS-4 and SS-8 produced 410 and $436 \mathrm{mg} / \mathrm{L}$ sulfates ions at $8^{\text {th }}$ day of incubation, 
respectively, while these isolates produced 745 and $775 \mathrm{mg} / \mathrm{L}$ at $16^{\text {th }}$ day of incubation, respectively. Sulfate ions production due to SS-1, SS-2, SS-7, SS-11, SS-13 and SS-17 ranged from 259 to $385 \mathrm{mg} / \mathrm{L}$ at $8^{\text {th }}$ day of incubation. While, sulfate ions produced due to these isolates ranged from 527 to $712 \mathrm{mg} / \mathrm{L}$ at $16^{\text {th }}$ day of incubation. Rest of the strains produced sulfate ions with non-detectable range at $8^{\text {th }}$ day of incubation.

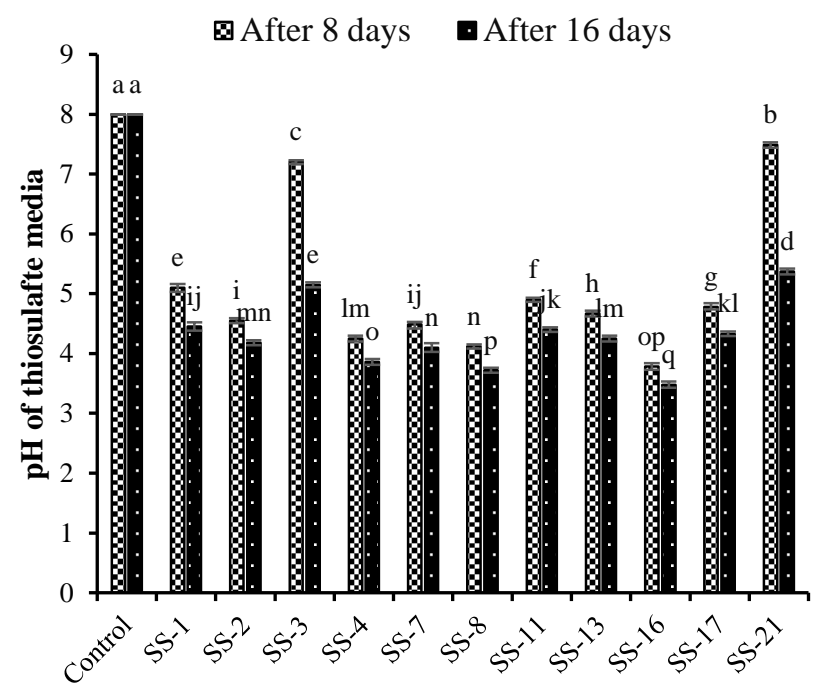

Figure 2. pH reduction in thiosulfate medium due to inoculation of SOB at $8^{\text {th }}$ and $16^{\text {th }}$ day of inoculation (average of three replicates).

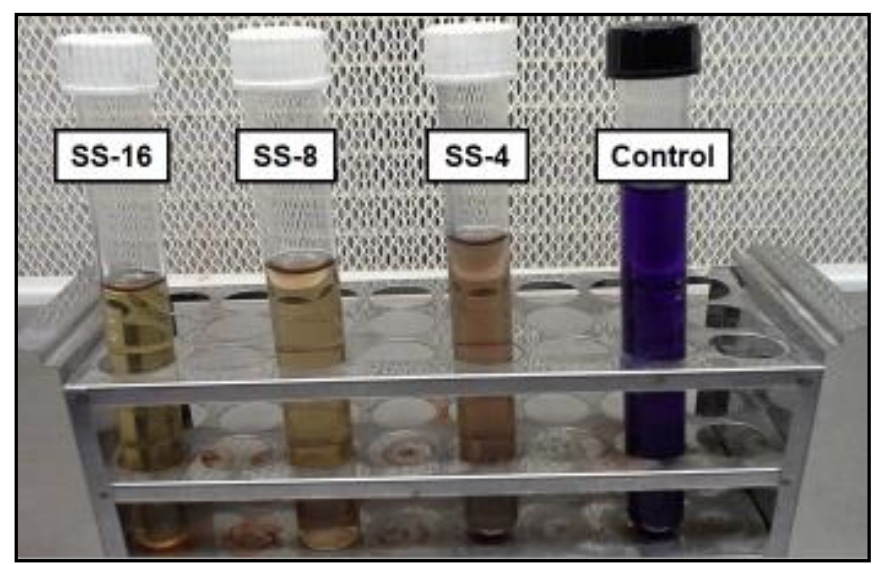

Figure 3. $\mathrm{pH}$ reduction test.

All eleven selected isolates were examined for phosphorus solubilization index (Fig. 5). According to data highest PSI (7.13) was observed in case of Bacillus sp. isolate SS-16 followed by isolate SS-8 with 6.56 PSI, while minimum PSI (1.2) was noted in case of isolate SS-21. PSI observed due to SS-1, SS-2, SS-3, SS-4, SS-7, SS-11, SS-13 and SS-17 was $1.64,4.59,1.39,5.26,5.27,2.31,3.82$ and 3.24 , respectively. No holozone was noticed in thiosulfate agar plates where no inoculation was done (control).



Figure 4. Sulfate ions production in thiosulfate medium due to inoculation of SOB at $8^{\text {th }}$ and $16^{\text {th }}$ day of inoculation (average of three replicates).

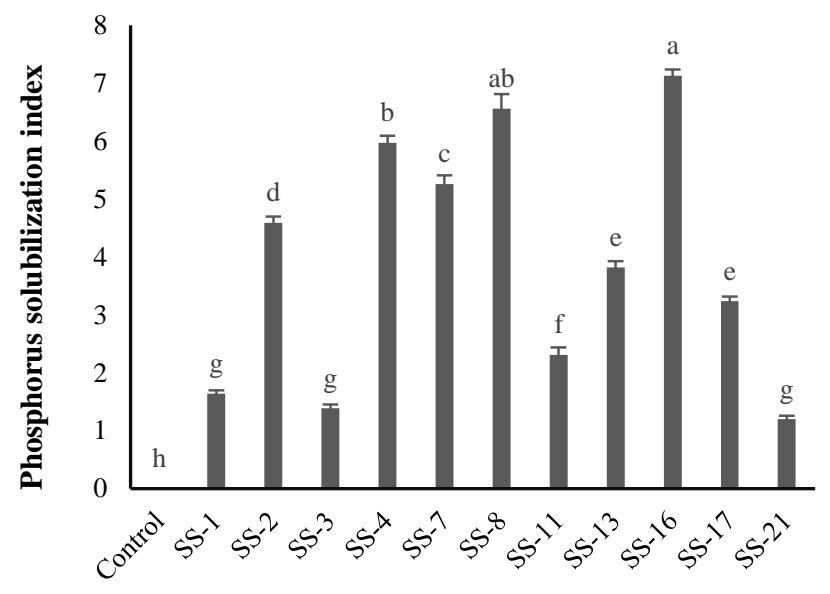

Figure 5. Phosphorus solubilization index of selected SOB (average of three replicates).

Quantitative analysis of phosphorus solubilization after inoculation (Fig. 6) revealed that Bacillus sp. isolate SS-16 dissolved 431 and $713 \mathrm{mg} / \mathrm{L}$ at $8^{\text {th }}$ and $16^{\text {th }}$ day of inoculation, respectively, followed by SS-8 that solubilized 391 and 681 $\mathrm{mg} / \mathrm{L}$ phosphorus at $8^{\text {th }}$ and $16^{\text {th }}$ day of inoculation, respectively. Minimum phosphorus solubilization of 41 and $169 \mathrm{mg} / \mathrm{L}$ was noted in case of SS-21 at $8^{\text {th }}$ and $16^{\text {th }}$ day of inoculation, respectively. Phosphorus solubilization due to rest of the isolates ranged from 63 to 375 and 220 to $646 \mathrm{mg} / \mathrm{L}$ at $8^{\text {th }}$ and $16^{\text {th }}$ day of inoculation, respectively. No dissolution was detected in case where no inoculation was done (control). Figures 7 and 8 show the resistance of selected eleven isolates to different concentrations of $\mathrm{Pb}$ and $\mathrm{Cd}$ in terms of MIC and MBC. Tolerance test indicated that isolates SS-1 and Bacillus sp. strain SS-16 showed highest resistance to $\mathrm{Pb}(1000 \mathrm{mg} / \mathrm{L}$ 
MIC) each followed by SS-7 which survived under $900 \mathrm{mg} / \mathrm{L}$ $\mathrm{Pb}$. Similarly, under cadmium stress, these isolates SS-1 and Bacillus sp. strain SS-16 showed the maximum MIC (180 $\mathrm{mg} / \mathrm{L} \mathrm{Cd}$ ), followed by SS-7 with $140 \mathrm{mg} / \mathrm{L} \mathrm{Cd} \mathrm{MIC}$. Minimum tolerance in term of MIC for $\mathrm{Pb}(300 \mathrm{mg} / \mathrm{L} \mathrm{Pb})$ and $\mathrm{Cd}(40 \mathrm{mg} / \mathrm{L} \mathrm{Cd})$ was recorded in case of SS-11. Rest of the strains showed different response to the different levels of $\mathrm{Pb}$ and $\mathrm{Cd}$.

For MBC test, isolates SS-1 and Bacillus sp. strain SS-16 showed highest resistance to $\mathrm{Pb}(1200 \mathrm{mg} / \mathrm{L} \mathrm{MBC})$ each followed by SS-7 with $1000 \mathrm{mg} / \mathrm{L} \mathrm{Pb}$. Similarly, under cadmium stress, these isolates SS-1 and Bacillus sp. strain SS16 showed the maximum MBC $(200 \mathrm{mg} / \mathrm{L} \mathrm{Cd})$ each followed by SS-21 with $180 \mathrm{mg} / \mathrm{L} \mathrm{Cd} \mathrm{MBC}$. Minimum tolerance in term of $\mathrm{MBC}$ for $\mathrm{Pb}(400 \mathrm{mg} / \mathrm{L} \mathrm{Pb})$ and $\mathrm{Cd}(60 \mathrm{mg} / \mathrm{L} \mathrm{Cd})$ was recorded in case of SS-11. Rest of the strains showed different response to the different levels of $\mathrm{Pb}$ and $\mathrm{Cd}$.

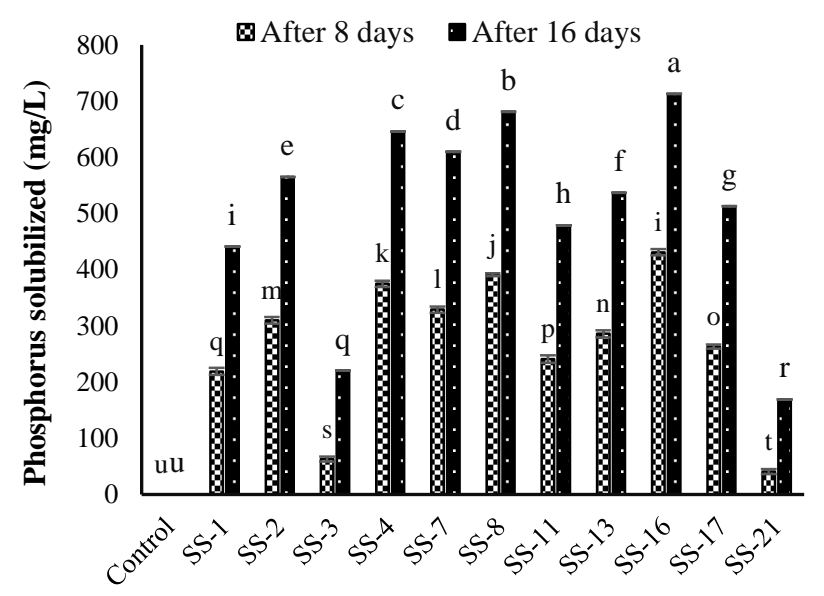

Figure 6. Quantification of $P$ solubilization through bioleaching test (average of three replicates).

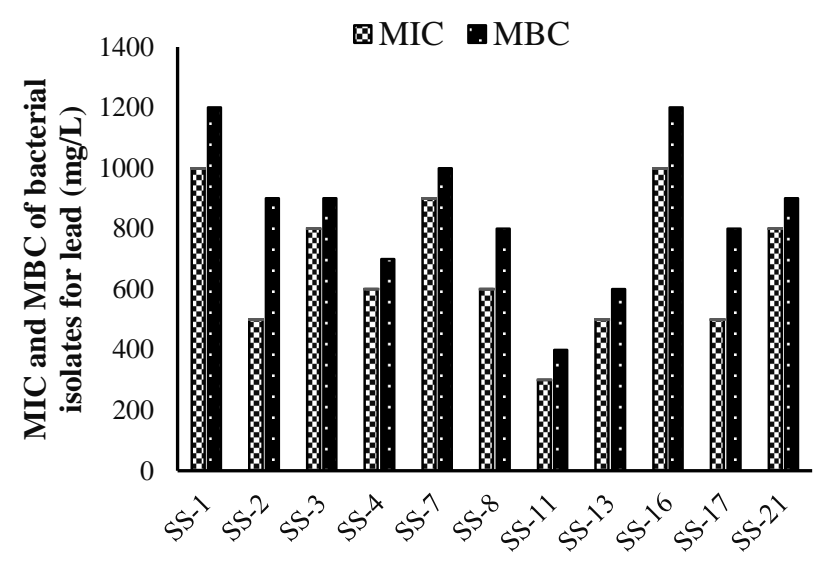

Figure 7. Minimum inhibitory concentration (MIC) and minimum bacterial concentration (MBC) of $\mathrm{Pb}$ for SOB isolates (average of three replicates).

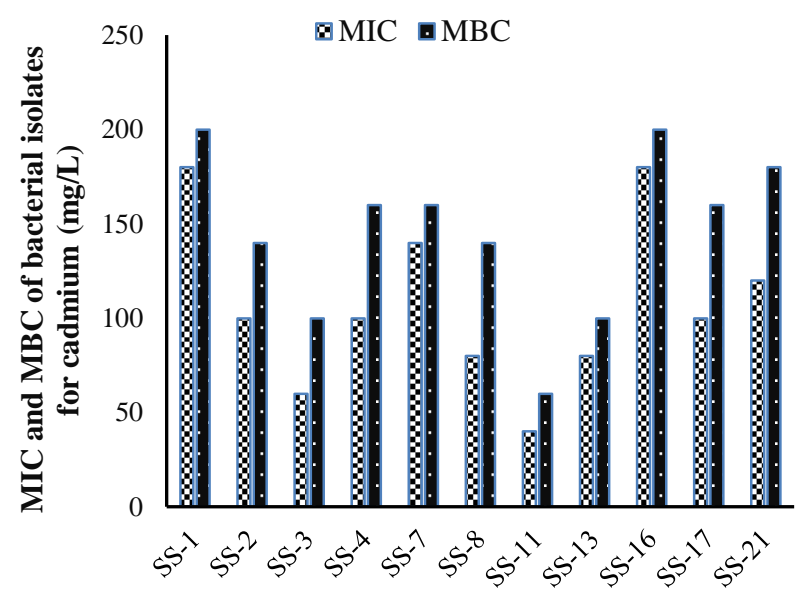

Figure 8. Minimum inhibitory concentration (MIC) and minimum bacterial concentration (MBC) of $\mathrm{Cd}$ for SOB isolates (average of three replicates).

Different organic acids were determined in the culture of strains SS-4, SS-8 and Bacillus sp. strain SS-16 under normal and stressed $(\mathrm{Pb}$ and $\mathrm{Cd})$ conditions (Table 1). Under normal conditions, major organic acid in the profile of SS-4 was tartaric acid $(362 \mu \mathrm{g} / \mathrm{mL})$ and the lowest was pyruvic acid $(1.03 \mu \mathrm{g} / \mathrm{mL})$. Fumaric acid was the second most abundant organic acid with $342 \mu \mathrm{g} / \mathrm{mL}$ amount in the profile. Under $\mathrm{Pb}$ stress, pyruvic acid increased from 1.03 to $1766 \mu \mathrm{g} / \mathrm{mL}$. Similarly, tartaric acid increased from 362 to $1613 \mu \mathrm{g} / \mathrm{mL}$. Other acids decreased approximately $100 \mu \mathrm{g} / \mathrm{mL}$ in $\mathrm{Pb}$ stress compared to normal conditions.

In the acid profile of SS-8, production of different acids varies in normal and stressed conditions. Highest amount of tartaric acid was observed under normal conditions while this acid increased under $\mathrm{Pb}$ and $\mathrm{Cd}$ stressed conditions up to 1750 and $1638 \mu \mathrm{g} / \mathrm{mL}$, respectively. Pyruvic acid also increased under $\mathrm{Pb}$ and $\mathrm{Cd}$ stressed conditions. In the profile of Bacillus sp. strain SS-16, major organic acid was tartaric $(826 \mu \mathrm{g} / \mathrm{mL})$ while the lowest was oxalic acid $(2.15 \mu \mathrm{g} / \mathrm{mL})$ under normal conditions. Under $\mathrm{Pb}$ stress, pyruvic acid was highest (1570 $\mu \mathrm{g} / \mathrm{mL}$ ) while the second major acid in the profile of Bacillus sp. strain SS-16 was tartaric acid $(1424 \mu \mathrm{g} / \mathrm{mL})$ and lowest was succinic acid $(7.23 \mu \mathrm{g} / \mathrm{mL})$. Under Cd stress, highest amount of tartaric acid was $1798 \mu \mathrm{g} / \mathrm{mL}$. Pyruvic acid also increased as compared to unstressed condition. Citric and malonic acids also increased under $\mathrm{Pb}$ stress as compared to unstressed condition.

The biochemical characterization of the isolated SOB was performed (Table 2). It is evident from the results that $\mathrm{SOB}$ strains SS-2, SS-3, SS-7, SS-8, SS-13, Bacillus sp. strain SS16 and SS-21 were Gram positive while the other four strains SS-1, SS-4, SS-11 and SS-17 were Gram negative. Amongst 11 SOB strains 6 strains SS-2, SS-4, SS-7, SS-8, SS-13 and Bacillus sp. strain SS-16 utilized elemental sulfur. SS-2, SS- 
Table 1. Organic acid profile from the cell culture of SS-4, SS-8 and SS-16 under normal, lead and cadmium stressed conditions (average of three replicates).

\begin{tabular}{|c|c|c|c|c|}
\hline Treatment & Organic acids $(\mu \mathrm{g} / \mathrm{mL})$ & SS-4 & SS-8 & SS-16 \\
\hline \multirow{9}{*}{$\begin{array}{l}\bar{\Xi} \\
\text { हु } \\
\text { z }\end{array}$} & Pyruvic acid & $1.03 \pm 0.01$ & $514.96 \pm 2.96$ & $560.32 \pm 2.46$ \\
\hline & Tartaric acid & $362.34 \pm 4.14$ & $733.97 \pm 4.22$ & $826.51 \pm 6.24$ \\
\hline & Citric acid & $48.77 \pm 0.56$ & $67.02 \pm 0.39$ & $64.38 \pm 0.49$ \\
\hline & Oxalic acid & $2.97 \pm 0.03$ & $1.03 \pm 0.01$ & $2.15 \pm 0.02$ \\
\hline & Malic acid & $135.39 \pm 1.55$ & $251.39 \pm 1.44$ & $249.30 \pm 1.88$ \\
\hline & Methyl malonic acid & $176.28 \pm 2.02$ & $1.13 \pm 0.01$ & $2.18 \pm 0.02$ \\
\hline & Malonic acid & $178.81 \pm 2.04$ & $11.42 \pm 0.07$ & $11.69 \pm 0.09$ \\
\hline & Fumeric acid & $342.10 \pm 3.91$ & $285.34 \pm 1.64$ & $262.63 \pm 1.98$ \\
\hline & Succinic acid & $105.73 \pm 1.21$ & $3.26 \pm 0.02$ & $4.18 \pm 0.03$ \\
\hline \multirow{9}{*}{ 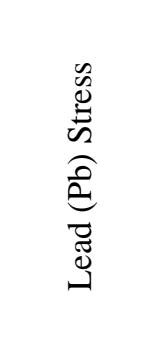 } & Pyruvic acid & $1766.13 \pm 7.75$ & $1070.87 \pm 4.70$ & $1570.43 \pm 6.89$ \\
\hline & Tartaric acid & $1400.85 \pm 10.6$ & $1750.18 \pm 13.2$ & $1412.25 \pm 10.7$ \\
\hline & Citric acid & $189.26 \pm 1.43$ & $4.18 \pm 0.03$ & $261.04 \pm 1.97$ \\
\hline & Oxalic acid & $2.04 \pm 0.02$ & $3.84 \pm 0.03$ & $13.32 \pm 0.10$ \\
\hline & Malic acid & $228.28 \pm 1.72$ & $27.81 \pm 0.21$ & $270.50 \pm 2.04$ \\
\hline & Methyl malonic acid & $1.05 \pm 0.01$ & $5.20 \pm 0.04$ & $8.24 \pm 0.06$ \\
\hline & Malonic acid & $3.26 \pm 0.02$ & $2.97 \pm 0.02$ & $293.78 \pm 2.22$ \\
\hline & Fumeric acid & $268.78 \pm 2.03$ & $8.03 \pm 0.06$ & $293.85 \pm 2.22$ \\
\hline & Succinic acid & $39.95 \pm 0.30$ & $8.24 \pm 0.06$ & $7.23 \pm 0.05$ \\
\hline \multirow{9}{*}{ 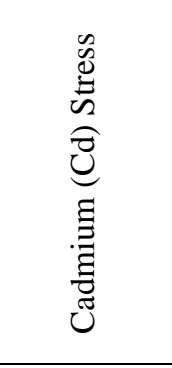 } & Pyruvic acid & $824.05 \pm 3.61$ & $911.35 \pm 4.00$ & $824.05 \pm 3.61$ \\
\hline & Tartaric acid & $1638.16 \pm 12.4$ & $1798.99 \pm 13.6$ & $1638.16 \pm 12.4$ \\
\hline & Citric acid & $21.42 \pm 0.16$ & $12.38 \pm 0.09$ & $21.42 \pm 0.16$ \\
\hline & Oxalic acid & $9.15 \pm 0.07$ & $7.23 \pm 0.05$ & $9.15 \pm 0.07$ \\
\hline & Malic acid & $22.53 \pm 0.17$ & $347.13 \pm 2.62$ & $22.53 \pm 0.17$ \\
\hline & Methyl malonic acid & $12.20 \pm 0.09$ & $8.24 \pm 0.06$ & $12.20 \pm 0.09$ \\
\hline & Malonic acid & $210.06 \pm 1.59$ & $18.27 \pm 0.14$ & $210.06 \pm 1.59$ \\
\hline & Fumeric acid & $1180.79 \pm 8.91$ & $309.10 \pm 2.33$ & $1180.79 \pm 8.91$ \\
\hline & Succinic acid & $747.88 \pm 5.64$ & $4.18 \pm 0.03$ & $747.88 \pm 5.64$ \\
\hline
\end{tabular}

Means are written with standard error (mean $\pm \mathrm{SE}$ )

Table 2. Morphological and biochemical characterization of SOB.

\begin{tabular}{lccccccccccc}
\hline Characteristics & \multicolumn{10}{c}{ Isolates } \\
\cline { 2 - 12 } & SS-1 & SS-2 & SS-3 & SS-4 & SS-7 & SS-8 & SS-11 & SS-13 & SS-16 & SS-17 & SS-21 \\
\hline Morphology & C & SR & C & SR & SR & SR & SR & SR & SR & SR & C \\
Gram reaction & - & + & + & - & + & + & - & + & + & - & + \\
Colony character & SIY & SRW & SIW & SRW & SRW & SRW & SRW & SRY & SRW & SRY & SIW \\
Catalase & - & + & - & + & - & + & - & + & + & - & - \\
Oxidase & + & + & - & + & + & + & + & + & + & + & - \\
Siderophore & - & + & - & + & - & + & - & - & + & + & - \\
$\mathrm{S}^{\circ}$ utilization & - & + & - & + & + & + & - & + & + & - & - \\
pH reduction & + & ++ & + & +++ & ++ & +++ & + & ++ & +++ & + & + \\
Growth at $5^{\circ} \mathrm{C}$ & - & + & - & + & + & + & - & + & + & - & - \\
Growth at $28^{\circ} \mathrm{C}$ & +++ & +++ & +++ & +++ & +++ & +++ & +++ & +++ & +++ & +++ & +++ \\
Growth at $38^{\circ} \mathrm{C}$ & ++ & +++ & ++ & +++ & +++ & +++ & ++ & +++ & +++ & ++ & ++ \\
Growth at $45^{\circ} \mathrm{C}$ & ++ & ++ & - & ++ & ++ & ++ & ++ & ++ & ++ & ++ & - \\
\hline
\end{tabular}

+ve sign shows the presence while -ve sign shows absence of the character, C: cocci, SR: small rod, SIY: smooth, irregular, yellow,

SRW: smooth, round, white, SIW: smooth, irregular, white, SRY: smooth, round, yellow

4, SS-8, SS-13 and Bacillus sp. strain SS-16 were positive in catalase production while rest of the strains were negative. Except SS-3 and SS-21 isolates, all other isolates were positive in oxidase production. Similarly, SS-2, SS-4, SS-8,
Bacillus sp. strain SS-16 and SS-17 showed siderophore production while remaining strains were negative in siderophore production.

Results of temperature tolerance test revealed that all 11 


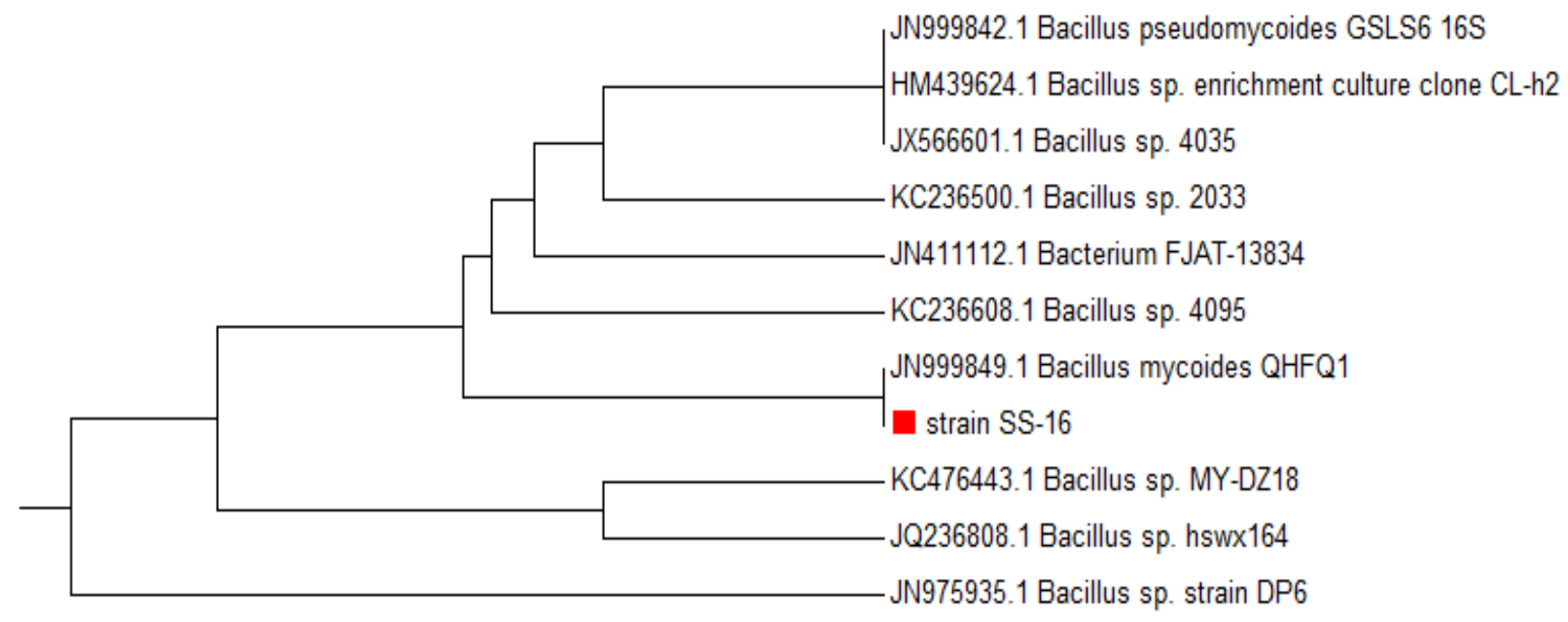

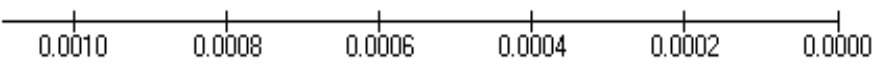

Figure 9. UPGMA phylogenetic analysis resulting from the multiple alignment of 16S rRNA gene sequence of Bacillus sp. with those of other bacterial strains found in Gene Bank database.

isolates were able to flourish in a wide range of temperature between $5-45^{\circ} \mathrm{C}$, however the optimum being $28-38^{\circ} \mathrm{C}$ as shown in Table 2. On the basis of the results of $\mathrm{pH}$ reduction, sulfate ions production and phosphorus solubilization tests and also phosphorus solubilization index, Bacillus sp. strain SS-16 was selected as most efficient SOB by using principle component analysis for identification. Factor coordinates of all sulfur oxidizing isolates are presented in Table 3. Maximum coordinate value (3.175) was observed in case of Bacillus sp. strain SS-16. The selected most efficient SOB isolate (SS-16) was identified as Bacillus sp. accession no. MF170226 using 16S rRNA technique.

Table 3. Factor coordinates of sulfur oxidizing bacteriaon the basis of pH reduction, sulfate ions production, phosphorus solubilization index and phosphorus bioleaching tests.

\begin{tabular}{lrrrrr}
\hline $\begin{array}{l}\text { Observa } \\
\text { tion }\end{array}$ & F1 & F2 & F3 & F4 & F5 \\
\hline Control & -5.367 & -1.175 & -0.324 & -0.010 & -0.009 \\
SS-1 & -0.307 & 0.547 & -0.674 & -0.112 & 0.027 \\
SS-2 & 1.283 & -0.060 & -0.083 & 0.049 & 0.031 \\
SS-3 & -3.174 & 0.574 & 0.606 & 0.050 & -0.064 \\
SS-4 & 2.216 & -0.247 & 0.223 & 0.007 & -0.040 \\
SS-7 & 1.657 & -0.180 & 0.075 & 0.097 & 0.043 \\
SS-8 & 2.602 & -0.314 & 0.336 & 0.009 & 0.006 \\
SS-11 & 0.072 & 0.427 & -0.534 & 0.003 & -0.060 \\
SS-13 & 0.903 & 0.108 & -0.251 & 0.074 & 0.024 \\
SS-16 & $\mathbf{3 . 1 7 5}$ & -0.367 & 0.370 & -0.147 & -0.019 \\
SS-17 & 0.522 & 0.225 & -0.341 & 0.032 & -0.005 \\
SS-21 & -3.583 & 0.462 & 0.597 & -0.053 & 0.066 \\
\hline
\end{tabular}

\section{DISCUSSION}

The study demonstrated that sewage sludge and cow dung are SOB enriched ecologies due to presence of sulfur or reduced sulfur compounds. SOB rely on sulfur oxidation for their energy demand (Pokorna et al., 2007). Phosphorous solubilizing potential of selected SOB through bacterially produced sulfuric acid as a result of sulfur oxidation has been explained in this study. Biological sulfur oxidation is an exceptional quality of SOB for oxidation of sulfur or sulfur compounds and generation of sulfuric acid. Thus, biological sulfur oxidation results in the production of sulfuric acid. SOB showed variance in their ability to oxidize sulfur. However, the most efficient isolate (Bacillus sp. strain SS-16) oxidized S compounds swiftly and generated sulfate ions in massive amount and dropped $\mathrm{pH}$ of thiosulfate medium. In agreement to our findings, variation in S oxidation by SOB isolates has also been reported in previous studies (Hassan et al., 2010; Yang et al., 2010).

Furthermore, highly efficient SOB (Bacillus sp. strain SS-16 and SS-8) generated sulfuric acid quickly and started making holozones from the first day of inoculation and as a result their phosphorus solubilization index (PSI) was very high (Islam et al., 2007). The strains with high PSI are documented highly effective in enhancing the solubilization of phosphorus in thiosulfate medium containing rock phosphate (Hariprasad and Niranjana, 2009; Ahemad and Khan, 2010). It has been reported earlier that during tricalcium phosphate bioleaching test, bacterially produced sulfuric acid not only solubilized phosphorus from tricalcium phosphate but also reduced the $\mathrm{pH}$ of thiosulafte medium (Ullah et al., 2014). The most 
efficient SOB produced huge concentration of sulfuric acid and dropped $\mathrm{pH}$ of medium within short period of time. Similarly, in the present study, most efficient SOB isolates (SS-8 and SS-16) decreased the $\mathrm{pH}$ during $\mathrm{pH}$ reduction test and enhanced the phosphorus solubilization. Hence, $\mathrm{pH}$ reduction in the thiosulfate medium signify the efficiency and potential of SOB for P solubilization (Aria et al., 2010; Oh et al., 2010; Ullah et al., 2013).

In the present study, efficient isolates (SS-8 and Bacillus sp. strain SS-16) produced highest quantity of sulfates in the sulfate ions production test. It has been reported in the previous studies that the sulfate concentration in leach solutions illustrated the fundamental potential of SOB to oxidize sulfur or sulfur compounds (Ullah et al., 2014). The most proficient SOB quickly oxidized sulfur compounds and generated sulfate ions that form sulfuric acid whereas less efficient SOB showed gradual sulfur oxidation ability and for that reason low level of sulfates were present in thiosulfate medium. So, SOB can be screened on account of quantity of sulfate ions present in their leach solutions (Lee et al., 2005; Yang et al., 2010).

Results of rock phosphate solubilization experiment have demonstrated that the isolates with highest sulfate ions production ability (SS-8 and Bacillus sp. strain SS-16) resulted in maximum solubilization of phosphorus from rock phosphate. On the other hand, isolated SOB with low sulfate ions production ability (SS-1 and SS-21) dissolved least amount of $\mathrm{P}$ form rock phosphate as detected in leach solutions. It revealed that the concentration of both sulfate ions as well as phosphorus increased in medium as a result of $\mathrm{pH}$ reduction (Bhatti and Yawar, 2010). Moreover, other selected isolates have potential to utilize elemental sulfur or thiosulphate and carbon dioxide as the only sources of energy and carbon, respectively. Moreover, they depicted great potential to generate sulfate ions intensively as a result of $\mathrm{pH}$ reduction of media (Kelly and Wood, 2000; Vidyalakshmi and Sridar, 2007; Babana et al., 2011).

Isolated SOB depicted their abilities to tolerate lead and cadmium concentrations (in terms of MIC and MBC) which might be associated with different adaptive mechanism such as change in shape and structure of the cell (Varghese, 2012; Abbas et al., 2014), production of organic acid (Li et al., 2009) and metabolites (Haferburg et al., 2009). Present study demonstrated that production of organic acids increased under $\mathrm{Pb}$ and $\mathrm{Cd}$ stressed conditions as compared to unstressed condition. Similar results have been observed by other researchers (Li et al., 2009; Jones, 1998; Ehrlich, 1998). It has been studied that inclusion of trace components to culture media can activate the production of numerous secondary organic acids and metabolites (Sprocati et al., 2006; Haferburg et al., 2009; Li et al., 2009). Further, Haferburg et al. (2009) proposed that production of different metabolites in response to trace component stress may be involved in detoxification of trace components by chelation. Li et al.
(2009) revealed that production of carboxylic acids from bacterial cells was activated by trace components and these acids have also been increased the mobility of different components in soil. It has also been reported that trace components in plant cells are detoxified by complexation with carboxylicacids (Salt et al., 1999; Kupper et al., 2004). Therefore, strains such as Bacillus sp. SS-16 that have ability to produce largest amount of organic acids in response to heavy metal stress can be used to detoxify metal contaminants in the soil and also to improve the growth of plants grown under metal stressed conditions.

Conclusion: Heavy metal tolerant sulfur oxidizing bacterium (Bacillus sp. SS-16) has potential of $\mathrm{pH}$ reduction, phosphorus solubilization and also organic acids production ability under $\mathrm{Pb}$ and $\mathrm{Cd}$ stressed conditions. Finally, it would be beneficial in future to investigate the effect of Bacillus sp. SS-16 on plant growth promotion under calcareous as well as heavy metal polluted soil to restore soil health in an environmentally sustainable way.

Acknowledgment: The authors would like to acknowledge the Institute of Soil \& Environmental Sciences, University of Agriculture, Faisalabad, Pakistan for providing research facilities.

\section{REFERENCES}

Abbas, S.Z., M. Rafatullah, N. Ismail and J. Lalung. 2014. Isolation, identification, and characterization of cadmium resistant Pseudomonas sp. M3 from industrial wastewater. J. Waste Manage. 2014:1-6.

Abdou, A.S. 2006. Effect of applied elemental sulfur and sulfur oxidizing bacteria (Parococcus versutus) into calcareous sandy soils on the availability of native and applied phosphorus and some micronutrients. The $18^{\text {th }}$ world congress of soil science, Philadelphia, Pennsylvania, USA, July. 9-15.

Ahemad, M. and M.S. Khan. 2010. Plant growth promoting activities of phosphate solubilizing Enterobacter asburiae as influenced by fungicides. Eur-Asia J. Biosci. 4:88-95.

Ali, H., E. Khan and M.A. Sajad. 2013. Phytoremediation of heavy metals concepts and applications. Chemosphere 91:869-881.

Alkorta, I. and C. Garbisu. 2001. Phytoremedation of organic contaminate in soils. Bioresource Technol. 79:273-276.

Amal, A.M., W.E.E. Eweda, A.M. Heggo and E.A. Hassan. 2014. Effect of dual inoculation with arbuscular mycorrhizal fungi and sulphur oxidising bacteria on onion (Allium cepa L.) and maize (Zea mays L.) grown in sandy soil under greenhouse conditions. Ann. Agric. Sci. 59:109-118.

Aria, M.M., A. Lakzian, G.H. Haghnia, A.R. Berenji, H. Besharati and A. Fotovat. 2010. Effect of Thiobacillus, 
sulfur, and vermicompost on the water soluble phosphorous of hard rock phosphate. Bioresour. Technol. 101:551-554.

Babana, A.H., F. Samake and K. Maiga. 2011. Characterization of some agricultural soils: presence and activity of Tilemsi rock phosphate solubilizing Thiobacilli. Brit. Microbiol. Res. J. 1:1-9.

Beijerinck, M.W. 1904. Phenomenes de reduction proguits parles microbes Arch. Sci. Exactes et Nat. Haarlem. Ser. 2:9131-9157.

Bergey, D.H. and D.R. Boone. 2009. Bergey's manual of systematic bacteriology. Springer Verlag.

Bhatti, T.M. and W. Yawar. 2010. Bacterial solubilization of phosphorus from phosphate rock containing sulfur mud. Hydrometallurgy 103:54-59.

Cha, J.M., W.S. Cha and J.H. Lee. 1999. Removal of organo sulphur odour compounds by Thiobacillus novellus SRM, sulphur oxidizing bacteria. Process Biochem. 34:659-665.

Cheneby, D., S. Perrez, C. Devroe, S. Hallet, Y. Couton, F. Bizouard, G. Iuretig, J.C. Germon and L. Philippot. 2004. Denitrifying bacteria in bulk and maize rhizospheric soil: Diversity and $\mathrm{N}_{2} \mathrm{O}$ reducing abilities. Can. J. Microbiol. 50:469-474.

Das, S.K., A.K. Mishra, B.J. Tindall, F.A. Rainey and E. Stackerbrandt. 1996. Oxidation of thiosulfate by a new bacterium, Bosea thiooxidans (strain BI-42) gen. nov., sp. nov.: analysis of phylogeny based on chemotaxanomy on $16 \mathrm{~S}$ ribosomal DNA sequencing. Int. J. Syst. Evol. Microbiol. 64:981-987.

Edi-Premono, M., A.M. Moawad and P.L.G. Vlek. 1996. Effect of phosphate solubilizing Pseudomonas putida on the growth of maize and its survival in the rhizosphere. Ind. J. Crop Sci. 11:13-23.

Ehrlich, H.L. 1998. Geomicrobiology: its significance for geology. Earth Sci. Rev. 45:45-60.

El-Tarabily, K.A., A.S. Abdou, E.S. Maher and M. Satoshi, 2006. Isolation and characterization of sulfuroxidizing bacteria, including strains of Rhizobium, from calcareous sandy soils and their effects on nutrient uptake and growth of maize (Zea mays L.). Aust. J. Agric. Res. 57:101-111.

Haferburg, G., I. Groth, U. Mollmann, E. Kothe, and I. Sattler. 2009. Arousing sleeping genes: shifts in secondary metabolism of metal tolerant actinobacteria under conditions of heavy metal stress. Biometals 22:225-234.

Hariprasad, P. and S.R. Niranjana. 2009. Isolation and characterization of phosphate solubilizing rhizobacteria to improve plant health of tomato. Plant Soil 316:13-24.

Hassan, S.H.A., W. Steven, V. Ginkel, S.M. Kim, S.H. Yoon, J.H. Joo, B.S. Shin, B.H. Jeon, W. Bae and S.E. Oh. 2010. Isolation and characterization of Acidithiobacillus caldus from a sulfur oxidizing bacterial biosensor and its role in detection of toxic chemicals. J. Microbiol. Methods 82:151-155.

Hitsuda, K., M. Yamada and D. Klepker. 2005. Sulfur requirement of eight crops at early stages of growth. J. Agron. 97:155-159.

Hussain, S.I. 2000. Irrigation of crops with sewage effluent: Implications and movement of lead and chromium as affected by soil texture, lime, gypsum and organic matter. Ph.D. Thesis, Dept. Soil Sci., Univ. Agri., Faisalabad, Pakistan.

Hussain, S., M. Devers-Lamrani, N. El-Azhari and F. MartinLaurent. 2011. Isolation and characterization of an isoproturon mineralizing Sphingomonas sp. strain $\mathrm{SH}$ from a French agricultural soil. Biodegr. 22:637-650.

Islam, M.T., A. Deoraa, Y. Hashidokoa, A. Rahmana, T. Itoa and S. Taharaa. 2007. Isolation and identification of potential phosphate solubilizing bacteria from the rhizoplane of Oryza sativa L. cv. BR29 of Bangladesh. J. Biosci. 62:103-110.

Jafar, M.Z., M. Farooq, M.A. Cheema, I. Afzal, S.M.A. Basra, M.A. Wahid, T. Aziz and M. Shahid. 2012. Improving the performance of wheat by seed priming under saline conditions. J. Agron. Crop Sci. 198:38-45.

Jamal, A., Y.S. Moon and M.Z. Abdin, 2010. Sulphur: A general overview and interaction with nitrogen. Aust. J. Crop Sci. 4:523-529.

Jones, D.L. 1998. Organic acids in the rhizosphere: a critical review. Plant Soil 205:25-44.

Kafilzadeh, F., S. Abolahrar, M. Kargar and M. Ghodsi. 2010. Cadmium toxicity and spectrum of resistance/tolerance to cadmium by bacterial species isolated from water and sediments of the Kor, Fars province. J. Sch. Public Health Inst. Public Health Res. 8:69-80.

Kayser, A., K. Wenger, A. Keller, W. Attinger, H.R. Felix and S.K. Gupta. 2000. Enhancement of phytoextraction of $\mathrm{Zn}, \mathrm{Cd}$, and $\mathrm{Cu}$ from calcareous soil: the use of NTA and sulphur amendments. Environ. Sci. Technol. 34:17781783.

Kelly, D.P. and A.P. Wood. 2000. Reclassification of some species of Thiobacillus to the newly designated genera Acidithiobacillus gen. nov., Halothiobacillus gen. nov. and Thermithiobacillus gen. nov. Int. J. Syst. Evol. Microbiol. 50:511-516.

Kolmert, A., P. Wikstrom and K.B. Hallberg. 2000. A fast and simple turbidimetric method for the determination of sulfate in sulfate reducing bacterial cultures. J. Microbiol. Methods 41:179-184.

Kupper, H., A. Mijovilovich, W. Meyer-Klaucke and P.M.H. Kroneck. 2004. Tissue and age-dependent differences in the complexation of cadmium and zinc in the cadmium/zinc hyperaccumulator Thlaspi caerulescens (Ganges ecotype) revealed by X-ray absorption spectroscopy. Plant Physiol. 134:748-757. 
Lawrence, J.R. and J.J. Germida. 1991. Enumeration of sulfur oxidizing populations in Saskatchewan agricultural soils. Can. J. Soil Sci. 71:127-136.

Lee, E.Y., K.S. Cho and H.W. Ryu. 2005. Simultaneous removal of $\mathrm{H}_{2} \mathrm{~S}$ and $\mathrm{NH}_{3}$ in biofilter inoculated with Acidithiobacillus thiooxidans TAS. J. Biosci. Bioeng. 99:611-615.

Li, W., Z. Ye and M. Wong. 2009. Metal mobilization and production of short chain organic acids by rhizosphere bacteria associated with a $\mathrm{Cd} / \mathrm{Zn}$ hyperaccumulating plant, Sedum alfredii. Plant Soil 326:453-467.

MacFaddin, J.F. 1980. Biochemical tests for identification of medical bacteria, $2^{\text {nd }}$ Ed. Williams and Wilkins, Baltimore, USA.

Maimon, A., J. Khairiah, M.R. Ahmad, A. Aminah and B.S. Ismail. 2009. Comparative accumulation of heavy metals in selected vegetables, their availability and correlation in lithogenic and nonlithogenic fractions of soils from some agricultural areas in Malaysia. Adv. Environ. Biol. 3:314-321.

Mcgrath, S.P., A.M. Chaudri and K.E. Giller. 1995. Long term effects of metals in sewage sludge on soils, microorganisms and plants. J. Ind. Microbiol. 14:94-104.

Nascimento, C.W.A. and B. Xing. 2006. Phytoextraction: A review on enhanced metal availability and plant accumulation. J. Agric. Sci. 63:299-311.

NFDC. 1992. Status report on sulfur in Pakistan. NFDC Publication No.7:92. National Fertilizer Development Center, Planning and Development Division, Islamabad, Pakistan.

Oh, S.E., S.H.A. Hassan and S.W.G. Van. 2010. A novel biosensor for detecting toxicity in water using sulfur oxidizing bacteria. Sens. Actuators. B. Chem. 154:17-21.

Pokorna, B., M. Mandl, S. Borilova, P. Ceskova, R. Markova and O. Janiczek. 2007. Kinetic constant variability in bacterial oxidation of elemental sulfur. Appl. Environ. Microbiol. 73:3752-3754.

Prasad, M.N.V. and H.M.O. Freitas. 2003. Metal hyperaccumulation in plants: biodiversity prospecting for phytoremediation technology. Electron. J. Biotechnol. 6:285-305.

Priyanka, S., M. Sivaji and R. Sridar. 2014. Isolation and characterization of novel multifunctional sulfur oxidizing bacterium (SOB) and its use as biofertilizer. Int. Sci. J. $1: 28-34$.

Qadir, M., A. Ghafoor and G. Murtaza. 2000. Cadmium concentration in vegetables grown on urban soils irrigated with untreated municipal sewage. Environ. Dev. Sustain. 2:11-19.

Salt, D.E., N. Benhamou, M. Leszczyniecka and I. Raskin. 1999. A possible role for rhizobacteria in water treatment by plant roots. Int. J. Phytoremed. 1:67-69.
Schwyn, B. and J.B. Neilands. 1987. Universal chemical assay for the detection and determination of siderophores. Anal. Biochem. 160:47-56.

Shamim, S. and A. Rehman. 2012. Cadmium resistance and accumulation potential of Klebsiella pneumoniae Strain CBL-1 isolated from industrial wastewater. Pak. J. Zool. 44:203-208.

Sharif, M., M.S. Sarir and F. Rabi. 2000. Biological and chemical transformation of phosphorus in some important soil series of NWFP. Sarhad J. Agric. 16:587592.

Sharma, R.K. and M. Agrawal. 2006. Single and combined effects of cadmium and zinc on carrots: uptake and bioaccumulation. J. Plant Nutr. 29:1791-1804.

Sprocati, A.R., C. Alisi, L. Segre, F. Tasso, M. Galletti and C. Cremisini. 2006. Investigating heavy metal resistance, bioaccumulation and metabolic profile of a metallophile microbial consortium native to an abandoned mine. Sci. Total Environ. 366:649-658.

Starkey, R.L. 1935. Isolation of some bacteria which oxidize thiosulfate. Soil Sci. 39:197-220.

Steel, K.J. 1961. The oxidase reaction as a toxic tool. J. Gen. Microbiol. 25:297-306.

Steel, R.G.D., J.H. Torrie and D.A. Dickey. 1997. Principles and procedures of statistics. A biometrical approach, $3^{\text {rd }}$ Ed. McGraw Hill Book Co., Inc. New York, USA.

Sutaria, G.S., V.D. Vora, K.D. Rakholiya, J.T. Patel and K.N. Akbari 2016. Availability of sulphur and its relationship with basic soil properties under various crop sequences in soils of Rajkot district (Gujarat). Int. J. Agric. Sci. Res. 3:83-86.

Turgut, C., M.K. Pepe and T.J. Cutright. 2004. The effect of EDTA and citric acid on phytoremediation of $\mathrm{Cd}, \mathrm{Cr}$, and Ni from soil using Helianthus annuus. Environ. Pollut. 131:147-154.

Ullah, I., G. Jilani, K.S. Khan, M.S. Akhtar and M. Rasheed. 2014. Sulfur oxidizing bacteria from sulfur rich ecologies exhibit high capability of phosphorous solubilization. Int. J. Agric. Biol. 16:550-556.

Ullah, I., G. Jilani, M.I. Haq and A. Khan. 2013. Enhancing bioavailable phosphorous in soil through sulfur oxidation by Thiobacilli. Brit. Microbiol. Res. J. 3:378-392.

Varghese, R. 2012. Bioaccumulation of cadmium by Pseudomonas sp. isolated from metal polluted industrial region. Environ. Res. Eng. Manage. 61:58-64.

Vidyalakshmi, R. and R. Sridar. 2007. Isolation and characterization of sulphur oxidizing bacteria. J. Cult. Coll. 5:73-77.

Vincent, J.M. 1970. A manual for the practical study of the root nodule bacteria. Burgess and Son Ltd, Great Britain.

Watanabe, F.S. and S.R. Olsen. 1965. Test of an ascorbic acid method for determining phosphorus in water and $\mathrm{NaHCO}_{3}$ extracts from soil. Soil Sci. Soc. Amer. Proc. 29:677-678. 
Wei, S.H., Q.X. Zhou, X. Wang, W. Cao, L.P. Ren and Y.F. Song. 2004. Potential of weed species applied to remediation of soils contaminated with heavy metals. J. Environ. Sci. 16:868-873.

Yang, Z.H., K. Stoven, S. Haneklaus, B.R. Singh and E. Schnug. 2010. Elemental sulfur oxidation by Thiobacillus sp. and aerobic heterotrophic sulfur oxidizing bacteria. Pedosphere 20:71-77.
Yoon, J., X. Cao, Q. Zhou and L.Q. Ma. 2006. Accumulation of $\mathrm{Pb}, \mathrm{Cu}$, and $\mathrm{Zn}$ in native plants growing on a contaminated Florida site. Sci. Total Environ. 368:456464.

Zeng, X., J. Tang, X. Liu and P. Jiang. 2009. Isolation, identification and characterization of cadmium resistant Pseudomonas aeruginosa strain $\mathrm{E}_{1}$. J. Cent. South Univ. T. 16:416-421. 